
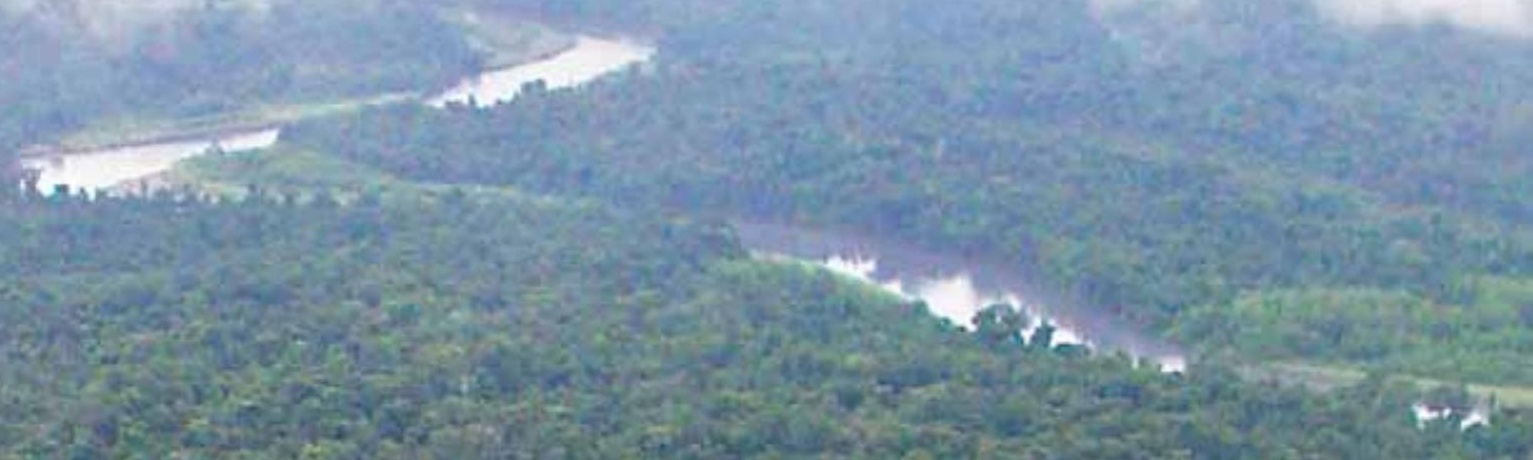

\title{
Moratorium Hutan Indonesia
}

Batu Loncatan untuk Memperbaiki Tata Kelola Hutan?

Daniel Murdiyarso

Sonya Dewi

Deborah Lawrence

Frances Seymour 

Working Paper 77

\title{
Moratorium Hutan Indonesia
}

\section{Batu Loncatan untuk Memperbaiki Tata Kelola Hutan?}

\author{
Daniel Murdiyarso \\ CIFOR \\ Sonya Dewi \\ World Agroforestry Centre \\ Deborah Lawrence \\ Department of Environmental Sciences, University of Virginia \\ Frances Seymour \\ CIFOR
}


Working Paper 77

(C) 2011 Center for International Forestry Research

Hak cipta dilindungi oleh undang-undang

Foto sampul oleh Daniel Murdiyarso

Murdiyarso, D., Dewi, S., Lawrence, D. dan Seymour, F. 2011 Moratorium Hutan Indonesia: Batu Loncatan untuk Memperbaiki Tata Kelola Hutan? Working Paper 77. CIFOR, Bogor, Indonesia.

Diterjemahkan dari: Murdiyarso, D., Dewi, S., Lawrence, D. and Seymour, F. 2011 Indonesia's forest moratorium: a stepping stone to better forest governance? Working Paper 76. CIFOR, Bogor, Indonesia.

CIFOR

Jl. CIFOR, Situ Gede

Bogor Barat 16115

Indonesia

$\mathrm{T}+62$ (251) 8622-622

F +62 (251) 8622-100

E cifor@cgiar.org

\section{www.cifor.org}

Semua pendapat yang dinyatakan dalam publikasi ini berasal dari para penulis dan tidak serta merta mencerminkan pendapat CIFOR, lembaga tempat bernaung penulis atau penyandang dana publikasi ini. 


\section{Daftar Isi}

Daftar Singkatan $\quad$ v

Ucapan Terima Kasih vi vi

Kata Pengantar vii

1 Latar Belakang 1

2 Ruang Lingkup Moratorium 2

3 Mengapa Moratorium Dipersoalkan? 5

3.1 Menggunakan Definisi yang Membingungkan 5

3.2 Memasukkan Hutan Lindung dan Hutan Konservasi yang Telah Dilindungi 5

3.3 Membuat Pengecualian yang Berpotensi Menimbulkan Masalah Baru 6

4 Kemungkinan Dampak Moratorium $\quad 8$

4.1 Dampak Lingkungan $\quad 8$

$\begin{array}{ll}\text { 4.2 Dampak Ekonomi } & 10\end{array}$

5 Melangkah ke Depan dengan Keterbukaan 11

6 Kesimpulan 14

7 Daftar Pustaka $\quad 15$ 


\section{Daftar Gambar, Tabel dan Kotak}

\section{Gambar}

1. Diagram Venn luas kawasan hutan primer, lahan gambut dan kawasan konservasi yang terdiri dari hutan konservasi dan hutan lindung, serta Peta Indikatif Penundaan Izin Baru

2a. Sebaran gambut menurut kedalaman di Provinsi Riau

2b. Sebaran gambut menurut kedalaman yang ditumpangtindihkan dengan kawasan hutan di Provinsi Riau

2c. Sebaran gambut menurut kedalaman di Provinsi Kalimantan Tengah

2d. Sebaran gambut menurut kedalaman yang ditumpangtindihkan dengan kawasan hutan di Provinsi Kalimantan Tengah

3. Peluang untuk meningkatkan manfaat moratorium dengan urutan sesuai tingkat kesulitannya

\section{Tabel}

1. Luas kawasan menurut pulau yang sesungguhnya dicakup moratorium (dalam juta ha), sebagaimana ditunjukkan oleh perbandingan kawasan konservasi dan cakupan Peta Indikatif Penundaan Izin Baru

2. Sebaran gambut menurut kedalaman di tiga pulau utama Indonesia (dalam ribu ha)

\section{Kotak}

1. Perubahan status lahan hutan di Kalimantan Tengah yang terjadi akhir-akhir ini

2. Pemanfaatan moratorium untuk meningkatkan tata kelola hutan 


\section{Daftar Singkatan}

$\begin{array}{ll}\text { AMDAL } & \text { Analisis mengenai dampak lingkungan } \\ \text { APL } & \text { Area untuk Penggunaan Lain } \\ \text { Bappenas } & \text { Badan Perencanaan Pembangunan Nasional } \\ \text { CO }_{2} & \text { Karbon dioksida } \\ \text { COP } & \text { Conference of Parties } \\ & \text { Konferensi Para Pihak } \\ \text { DAS } & \text { Daerah Aliran Sungai } \\ \text { FAO } & \text { Food and Agriculture Organization of the United Nations } \\ & \text { Organisasi Pangan dan Pertanian PBB } \\ \text { ha } & \text { Hektar } \\ \text { HNKT } & \text { Hutan dengan Nilai Konservasi Tinggi } \\ \text { HPH } & \text { Hak Pengusahaan Hutan } \\ \text { Inpres } & \text { Instruksi Presiden } \\ \text { KK } & \text { Kawasan Konservasi } \\ \text { LoI } & \text { Letter of Intent } \\ & \text { Surat Pernyataan Kehendak (antara Pemerintah Indonesia dan Norwegia) } \\ \text { MIFEE } & \text { Lumbung Pangan dan Energi Terpadu Merauke (Papua) } \\ \text { MRV } & \text { Monitoring, Reporting and Verification } \\ & \text { Pemantauan, pelaporan dan pembuktian } \\ \text { PIPIB } & \text { Peta Indikatif Penundaan Izin Baru } \\ \text { REDD } & \text { Reducing emission from deforestation and forest degradation } \\ \text { UKL } & \text { Pengurangan emisi dari deforestasi dan degradasi hutan } \\ \text { UNFCCC } & \text { Upaya Pengelolaan Lingkungan } \\ \text { UPL } & \text { Konvensi Kerangka Kerja Perserikatan Bangsa Bangsa mengenai Perubahan Iklim } \\ & \text { Upaya Pemantauan Lingkungan } \\ & \end{array}$




\section{Ucapan terima kasih}

Penelitian ini tidak mungkin terlaksana tanpa bantuan Direktorat Jenderal Planologi, Kementerian Kehutanan, yang atas permintaan kami telah menyediakan kemudahan untuk memperoleh peta tutupan hutan digital. Kami juga menyampaikan penghargaan atas sumbangsih nyata dari para rekan kerja di Bagian Analisis Tata Ruang, World Agroforestry Centre, Bogor, Indonesia.

Terima kasih juga kami sampaikan kepada Gary Paoli dan Philip Wells dari Daemeter Consulting yang telah memeriksa pekerjaan kami. Ulasan kritis dan saran mereka telah menyempurnakan naskah ini. Kami juga menyampaikan terima kasih kepada Mubariq Achmad dari Bank Dunia atas tanggapan dan masukannya yang mendalam. Apabila masih ada kekeliruan dalam makalah ini tentu saja merupakan tanggung jawab kami.

Kami juga mendapat kesempatan berharga untuk membahas secara terbuka bersama beberapa rekan kerja di Kementerian Kehutanan, khususnya Badan Penelitian dan Pengembangan Kehutanan (FORDA). Kami dapat saling memahami dan mencapai mufakat atas sejumlah persoalan dan kami berharap agar analisis ini dapat menjadi titik tolak bagi kerja sama pada masa mendatang.

Publikasi ini terlaksana atas dukungan dari Australian Agency for International Development, the Climate and Land Use Alliance, Pemerintah Kerajaan Norwegia dan World Agroforestry Centre. 


\section{Kata Pengantar}

Pada tanggal 20 Mei 2011, Pemerintah Indonesia menerbitkan Instruksi Presiden (Inpres) No. 10/2011 tentang penundaan penerbitan izin baru dan penyempurnaan tata kelola hutan alam primer dan lahan gambut. Inpres ini merupakan bagian dari kerja sama Indonesia dengan Pemerintah Kerajaan Norwegia, berdasarkan Surat Pernyataan Kehendak (LoI) yang ditandatangani oleh kedua belah pihak pada tanggal 26 Mei 2010. Inpres tersebut, yang mendorong moratorium selama dua tahun atas izin hak pengusahaan hutan (HPH) baru, menimbulkan wacana publik secara luas dan memiliki implikasi terhadap sejumlah kebijakan penting.

Analisis ini dilakukan dalam rangka memberi masukan terhadap upaya perbaikan tata kelola hutan di Indonesia. Makalah ini diharapkan dapat membantu para pemerhati yang tertarik dalam memahami kekhawatiran yang diungkapkan oleh berbagai kelompok pemangku kepentingan. Kami memulai dengan memeriksa sejumlah batasan dan peristilahan yang digunakan dalam Inpres dan LoI tersebut untuk memahami tingkat kerumitan persoalan. Kemudian, untuk memberi masukan kepada pemerintah, kami mencermati Peta Indikatif Penundaan Izin Baru (PIPIB) yang dilampirkan dalam Inpres tersebut. Fokus analisis kami khususnya mengenai tantangan yang terkait dengan lahan gambut, ekosistem kaya karbon yang lemah tata kelolanya. Kami juga berusaha menunjukkan hubungan antara moratorium dan upaya penurunan emisi karena moratorium tersebut berpotensi menciptakan keadaan yang memungkinkan mitigasi perubahan iklim, walaupun ruang lingkup dan masa berlakunya terbatas.

Pada akhirnya, kami berharap agar analisis ini memberi sumbangsih bagi proses penyempurnaan PIPIB yang sekarang tersedia untuk umum.

Daniel Murdiyarso

Sonya Dewi

Deborah Lawrence

Frances Seymour 



\section{Pesan Pokok}

- Moratorium selama dua tahun mengenai penangguhan pemberian izin HPH baru di hutan alam primer dan kawasan lahan gambut merupakan langkah penting dalam memenuhi komitmen sukarela Indonesia untuk mengurangi emisi gas rumah kaca. Namun demikian, ada beberapa persoalan yang belum tuntas mengenai luas dan status lahan yang tercakup dalam moratorium ini. Demikian juga mengenai jumlah karbon yang tersimpan di hutan dan lahan gambut yang terkait.

- Luas kawasan yang dicakup moratorium adalah 22,5 juta hektar (ha), yang terdiri dari 7,2 juta ha hutan primer, 11,2 juta ha lahan gambut dan 4,1 juta ha yang tidak termasuk dalam kedua kategori tersebut.

- Kenyataan bahwa moratorium tidak mencakup hutan sekunder dan areal bekas tebangan menunjukkan hilangnya kesempatan untuk melindungi, paling sedikit untuk sementara, 46,7 juta ha hutan lainnya yang masih kaya akan karbon dan keanekaragaman hayati.

- Pemberlakuan moratorium bagi lahan gambut akan memberikan manfaat lingkungan yang paling nyata karena kapasitas simpan karbonnya yang besar. Namun demikian, karena tata kelolanya relatif lemah, akan diperlukan upaya bersama untuk mengambil manfaat ini.

- Sejumlah kegiatan yang mendapat pengecualian dalam moratorium ini, yang berkaitan dengan ketahanan pangan dan energi, menciptakan celah yang dapat merongrong penangguhan izin HPH baru. Kemungkinan untuk tukar-guling lahan yang ramah lingkungan dan laik secara ekonomi perlu dipelajari sebelum sejumlah pengecualian tersebut dilaksanakan.

- Peta Indikatif Penundaan Izin Baru (PIPIB) yang terus-menerus diperbarui akan menjadi alat penting bagi masyarakat untuk mencermati dan menjadi mekanisme untuk lebih mengamankan dan mungkin menambah kawasan yang dicakup dalam moratorium ini. Sebagai bagian dari proses ini, izin yang ada perlu ditinjau kembali dalam hal penaatan terhadap undang-undang dan peraturan yang berlaku.

\section{Latar Belakang}

Pengurangan emisi dari deforestasi dan degradasi hutan (REDD) disepakati di Bali pada Sesi ke-13 Konferensi Para Pihak (COP 13) Konvensi Kerangka Kerja PBB mengenai Perubahan Iklim (UNFCCC), sebagai mekanisme global untuk mitigasi perubahan iklim ${ }^{1}$. Mekanisme yang sekarang disebut REDD+ ini meliputi rangkaian kegiatan yang lebih luas, termasuk konservasi hutan, pengelolaan hutan secara lestari dan peningkatan cadangan karbon melalui penghutanan (aforestasi) dan penghutanan kembali $(\text { reboisasi })^{2}$.

Pada tanggal 26 Mei 2010, pemerintah Republik Indonesia dan Kerajaan Norwegia menandatangani Surat Pernyataan Kehendak (LoI) tentang REDD ${ }^{3}$.

1 Decision 2/CP.13. Reducing emissions from deforestation in developing countries: approaches to stimulate action. FCCC/ CP/2007/6/Add.1, pp. 8-11.

2 Decision 2/CP.15. Copenhagen Accord. FCCC/CP/2009/ 11/Add, pp. 4-9.

3 http://www.norway.or.id/PageFiles/404362/Letter_of_ Intent_Norway_Indonesia_26_May_2010.pdf.
Berdasarkan LoI ini, Indonesia sepakat untuk melakukan beberapa tindakan, antara lain:

- menyusun Strategi Nasional tentang REDD+;

- menetapkan badan khusus untuk menerapkan strategi REDD+, termasuk sistem pemantauan, pelaporan dan pembuktian (MRV) atas pengurangan emisi dan instrumen keuangan untuk penyaluran dana; dan

- mengembangkan dan menerapkan instrumen kebijakan serta kemampuan untuk melaksanakannya, termasuk penundaan selama dua tahun bagi pemberian izin HPH baru untuk konversi kawasan lahan gambut dan hutan alam untuk penggunaan lainnya.

Komitmen ini sesuai dengan janji sukarela Presiden Susilo Bambang Yudhoyono yang diumumkan tahun sebelumnya untuk mengurangi emisi gas rumah kaca Indonesia sebesar $26 \%$ pada tahun 2020 dengan sumber daya keuangan dalam negeri ${ }^{4}$ (atau sebesar

$4 \mathrm{http} / / /$ forestclimatecenter.org/files/2009-09-25\%20 Intervention $\% 20$ by $\% 20$ President $\% 20$ SBY $\% 20$ on $\% 20$ Climate\%20Change\%20at\%20the\%20G-20\%20Leaders\%20 Summit.pdf. 
41\% dengan bantuan internasional). Di lain pihak, Pemerintah Norwegia menjanjikan dana hingga AS\$1 miliar untuk mendukung sejumlah tindakan Indonesia.

Hanya satu minggu sebelum setahun penandatanganan LoI tersebut, pada 20 Mei 2011, Instruksi Presiden, yang dikenal dengan Inpres No. 10/2011 diterbitkan. Inpres ini mengumumkan moratorium hutan yang akan memenuhi salah satu tindakan kesepakatan dalam LoI yang paling banyak menarik perhatian publik ${ }^{5}$. Inpres ini bertujuan untuk menunda pemberian izin HPH baru untuk penebangan dan konversi hutan dan lahan gambut selama dua tahun sejak tanggal diundangkannya. Penundaan ini memungkinkan pembenahan tata kelola hutan yang lebih baik melalui pelembagaan proses koordinasi dan pengumpulan data dan kemungkinan juga peraturan-peraturan baru yang diperlukan.

Sementara CIFOR $^{6}$ dan sejumlah pihak lain menyambut baik moratorium ini sebagai langkah maju, dua kelompok pemangku kepentingan tertentu menyambut pengumuman ini dengan kecemasan yang berbeda alasannya ${ }^{7}$.

Pertama, kalangan pengusaha (dan sebagian anggota dewan dan birokrat) yang mengungkapkan kekhawatirannya bahwa dengan membatasi peluang pembangunan berbasis lahan, moratorium akan menghambat pertumbuhan ekonomi ${ }^{8}$. Mereka menegaskan bahwa moratorium dapat membahayakan strategi pembangunan yang mampu menciptakan lapangan kerja dan yang berpihak pada rakyat miskin yang telah diterima secara luas.

Kedua, kalangan pemerhati lingkungan yang kecewa atas ruang lingkup moratorium yang sempit dengan berbagai pengecualiannya. Mereka menyatakan bahwa moratorium tidak akan efektif untuk mengurangi emisi karbon dan mengungkapkan

5 http://sipuu.setkab.go.id/PUUdoc/17176/INPRES0102011.pdf.

6 CIFOR press release, 20 Mei 2011. Ban on new forest concessions in Indonesia is good news for climate change, but many challenges remain.

7 The Jakarta Globe, 22 Mei 2011. Forest moratorium too harsh for some, too weak for others.

8 Antara, 22 Mei 2011. GAPKI menganggap Inpres moratorium akan memicu perselisihan. kekhawatiran tentang lemahnya rencana tata ruang/tata guna lahan dan tata kelola hutan, yang diperlukan secara lebih luas untuk mendukung pelaksanaan moratorium ini. ${ }^{9}$

Makalah ini bertujuan untuk membantu para pihak yang tertarik untuk menafsirkan arti penting moratorium dan kekhawatiran yang diungkapkan oleh berbagai kelompok pemangku kepentingan. Analisis dalam makalah ini dapat dianggap sebagai sumbangan pemikiran kepada Pemerintah Indonesia dalam upaya menyempurnakan Peta Indikatif Penundaan Izin Baru (PIPIB) yang dilampirkan dalam Inpres tersebut. ${ }^{10}$

\section{Ruang Lingkup Moratorium}

Inpres merupakan seperangkat perintah presiden kepada kementerian dan lembaga pemerintahan lain yang terkait. Sebagai dokumen nonlegislatif, Inpres tidak memiliki konsekuensi hukum jika tidak dilaksanakan. Inpres No. 10/2011 memberi perintah kepada tiga menteri (Kehutanan, Dalam Negeri dan Lingkungan Hidup) dan kepala lima lembaga (Unit Kerja Presiden Bidang Pengawasan dan Pengendalian Pembangunan, Badan Pertanahan Nasional, Badan Koordinasi Penataan Ruang Nasional, Badan Koordinasi Survei dan Pemetaan Nasional dan lembaga yang dibentuk untuk mengelola REDD+), serta para gubernur dan bupati. Inpres ini menjelaskan tugas dan tanggung jawab masing-masing lembaga selama dua tahun sejak dikeluarkannya Inpres.

Dua kementerian penting yang sangat terkait dengan deforestasi dan emisi berbasis lahan tidak disebutkan dalam Inpres, yaitu: Kementerian Pertanian dan Kementerian Energi dan Sumber Daya Mineral. Kedua lembaga ini tidak dimasukkan dalam Inpres mungkin karena terkait dengan peran mereka dalam program ketahanan pangan dan energi nasional. Pembatasan penerapan moratorium pada kegiatan di sektor-sektor ini dapat melemahkan kemampuan

9 Kompas, 26 Mei 2011. Inpres, kompromi politik-ekonomi. 10 http://www.ukp.go.id/web/berita/10-umum/36-ajakankepada-masyarakat-untuk-memberikan-masukan-pembaharuanpeta-tutupan-hutan-dan-lahan-gambut. 
pemerintah untuk memenuhi tujuan Inpres itu sendiri, serta komitmen Presiden untuk menurunkan emisi gas rumah kaca.

Inpres ini berlaku bagi hutan alam primer dan lahan gambut. Istilah yang baru saja diperkenalkan 'hutan alam primer' - dan bukan 'hutan alam', sebagaimana digunakan dalam LoI - telah ditafsirkan berbeda oleh berbagai pemangku kepentingan. Istilah baru dalam Inpres ini menguatkan penafsiran bahwa sasaran moratorium hanya hutan yang tidak tersentuh, tidak terkelola dan tidak terganggu. Sedangkan sebagian pihak menafsirkan bahwa LoI mencakup kisaran hutan yang lebih luas. Penggunaan istilah 'hutan alam primer' juga mempengaruhi ruang lingkup moratorium karena tidak memasukkan hutan alam sekunder atau hutan bekas tebangan. Perbedaannya besar sekali - sebagaimana diuraikan lebih lanjut di bawah ini, karena jika menggunakan istilah 'hutan alam' luas kawasan yang tercakup moratorium dapat mencapai dua kali lipat, bergantung pada berapa bagian dari luas hutan ini yang telah diberi $\mathrm{HPH} .{ }^{11}$

Namun demikian, teks tentang lahan gambut dalam Inpres ini menyiratkan bahwa moratorium mencakup seluruh lahan gambut tanpa membedakan jenis, kedalaman, letak, wilayah administrasi dan tingkat kerusakannya. Sebelumnya, berdasarkan Peraturan Menteri Pertanian (No. 14/Permentan/ FL.110/2/2009), hanya lahan gambut dengan kedalaman lebih dari $3 \mathrm{~m}$ yang dilindungi dari konversi menjadi perkebunan kelapa sawit. Gubernur dan bupati, yang menerbitkan izin pengembangan kelapa sawit, perlu menafsirkan Inpres lebih bijaksana setelah sekian lama memegang peraturan menteri tersebut sebagai acuan.

Dalam hal luas lahan yang tercakup dalam moratorium, berbagai pejabat pemerintah membuat pernyataan yang berbeda-beda. Segera setelah Inpres ini diumumkan, Penasihat Presiden bidang Perubahan Iklim menyampaikan kepada masyarakat

11 Luas seluruh lahan berhutan di Indonesia pada tahun 2009 ialah 91,9 juta ha (paling sedikit 85,6 juta ha lahan hutan negara dan 6,2 juta ha lahan untuk areal penggunaan lain, atau 'APL'). Di antara luas ini, hutan primer mencakup 45,2 juta ha. Banyak di antara hutan primer ini telah dilindungi oleh hukum yang ada, yang selanjutnya mengurangi daerah tambahan yang dilindungi berdasarkan moratorium. Bahkan, seandainya sekitar 46,7 juta ha hutan nonprimer telah dilindungi, daerah yang tercakup dalam moratorium tersebut semestinya telah bertambah cukup besar. bahwa lahan yang tercakup moratorium adalah seluas 64 juta ha. ${ }^{12}$ Kemudian Sekretaris Jenderal Kementerian Kehutanan menyatakan bahwa lahan yang tercakup kira-kira 72 juta ha, yang terdiri dari 55 juta ha hutan primer dan 17 juta ha lahan gambut - yang jauh lebih kecil dari pengumuman sebelumnya, 96 juta ha. ${ }^{13}$ Dasar penyebutan angkaangka ini tidak dijelaskan (Wells dan Paoli 2011). Interpretasi independen secara digital terhadap PIPIB yang melampiri Inpres menunjukkan bahwa moratorium mencakup luas yang tidak lebih dari 46 juta ha. ${ }^{14}$ Sementara itu analisis yang dilakukan untuk makalah ini terhadap PIPIB - tersedia bagi umum pada tanggal 5 Agustus 2011 - menunjukkan bahwa luas cakupan Inpres adalah 66,4 juta ha.

Berbagai manfaat lingkungan yang akan diperoleh dari moratorium diperkirakan lebih kecil daripada yang mungkin diharapkan. Luas kawasan yang belum dilindungi masih sangat luas dan emisi yang dapat dihindari masih terlalu kecil. Untuk memperoleh perkiraan yang lebih tepat mengenai kedua hal ini, kami menumpangtindihkan peta digital hutan primer hasil interpretasi citra Landsat yang diperoleh pada tahun 2009 (Kementerian Kehutanan 2011) dengan peta digital kawasan yang ditetapkan sebagai hutan konservasi dan hutan lindung sejak 2009 (Kementerian Kehutanan 2009). Peta tata guna/tutupan lahan disediakan oleh Kementerian Kehutanan bagi CIFOR atas permintaan pada tahun 2011. Selanjutnya yang ditumpangtindihkan adalah peta digital lahan gambut yang disediakan oleh Wetlands International $(2003,2004,2006)$ dan PIPIB versi terbaru PIPIB.

Sebagaimana ditunjukkan pada Gambar 1, pada tahun 2009, luas hutan primer dan lahan gambut di Indonesia mencakup 60,1 juta ha. Karena banyak di antara daerah ini telah dilindungi secara hukum, luas kawasan yang dicakup moratorium hanya 22,5 juta ha $(7,2$ juta ha hutan primer, 11,2 juta ha lahan

12 The Jakarta Globe, 20 Mei 2011. SBY signs decree on 2-year deforestation moratorium; The Jakarta Post, 20 Mei 2011. Moratorium issued to protect primary forests, peatland.

13 The Jakarta Post, 5 Juli 2011. Govt reduces area of forests protected by moratorium.

14 http://www.greenpeace.org/seasia/id/blog/pak-presidensby-kami-akan-memberitahu-siapa-/blog/35150p. 


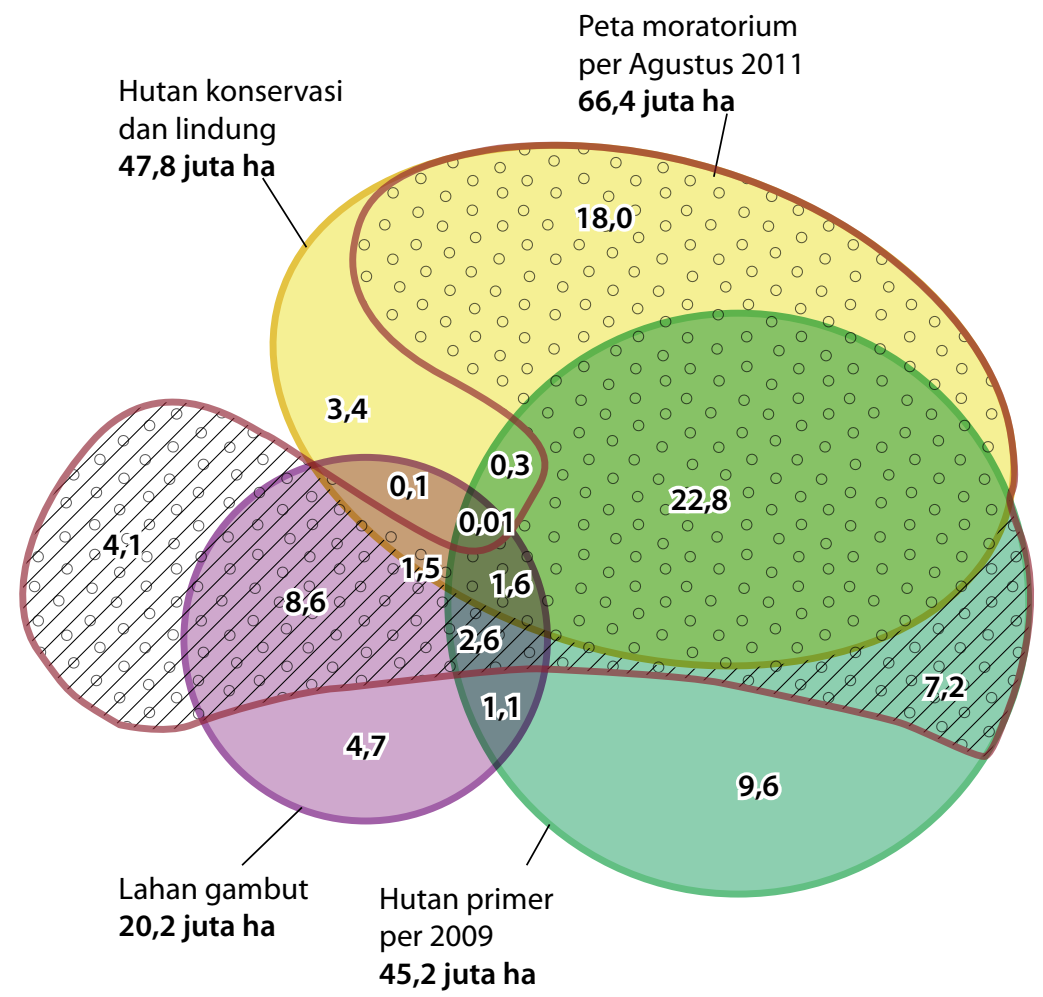

Hutan konservasi dan lindung yang tercakup dalam moratorium

Daerah yang sejak semula dan yang

belum lama tercakup dalam moratorium

Gambar 1. Diagram Venn luas kawasan hutan primer, lahan gambut dan kawasan konservasi yang terdiri dari hutan konservasi dan hutan lindung, serta Peta Indikatif Penundaan Izin Baru. Luas kawasan yang benar-benar hanya dicakup moratorium adalah 22,5 juta ha $(=7,2$ juta ha hutan primer $+2,6$ juta ha lahan gambut primer $+8,6$ juta ha lahan gambut sekunder $+4,1$ juta ha selain hutan primer atau lahan gambut).

Sumber: Wetlands International (2003, 2004, 2006), Kementerian Kehutanan (2011), Peta Indikatif Penundaan Izin Baru (Agustus 2011)

gambut dan 'tambahan' 4,1 juta ha ${ }^{15}$ yang tidak termasuk keduanya).

Dari gambar tersebut terdapat 5,8 juta ha lahan gambut (29\% seluruh lahan gambut nasional) yang tidak termasuk dalam PIPIB. Kemungkinan izinnya sudah diterbitkan sebelum Inpres, atau memang tidak disertakan dalam PIPIB karena sudah dicadangkan untuk kegiatan yang berkaitan dengan ketahanan pangan dan energi. PIPIB juga tidak mencakup 9,6 juta ha hutan primer (21\% seluruh hutan primer yang tersisa), yang terdiri dari 4,1 juta ha hutan produksi terbatas, 3,4 juta ha hutan produksi dan 1,8 juta ha hutan yang dapat dikonversi. Seperti halnya lahan gambut, kawasan hutan primer ini kemungkinan besar telah berada di bawah HPH yang izinnya sudah diberikan sebelum
Inpres, meskipun kenyataannya, hutan tersebut belum terganggu atau tidak dicadangkan untuk kegiatan yang berkaitan dengan ketahanan pangan dan energi.

Pengecualian terhadap moratorium meliputi izin $\mathrm{HPH}$ yang telah disetujui sebelum Inpres diumumkan. Berhubung peta HPH saat ini tidak tersedia untuk umum, kami tidak dapat menumpangtindihkannya pada peta yang tersedia atau memasukkannya ke dalam analisis diagram Venn (Gambar 1). Mungkin saja kawasan yang telah memiliki izin $\mathrm{HPH}$ ini tumpang tindih dengan PIPIB. Revisi PIPIB yang terbuka akan efektif apabila peta $\mathrm{HPH}$ dan peta penetapan kawasan hutan versi terbaru tersedia untuk umum.

15 Perbedaan ini terjadi karena, dalam melakukan analisis ini, kami menggunakan peta penetapan hutan dengan versi yang berbeda (Kementerian Kehutanan 2009) dari yang digunakan oleh Kementerian Kehutanan untuk membuat PIPIB tersebut. Versi lengkap peta terakhir ini belum tersedia bagi umum. 


\section{Mengapa Moratorium Dipersoalkan?}

Sejak awal, moratorium menimbulkan sejumlah persoalan yang diperdebatkan oleh sejumlah kelompok yang memiliki kepentingan. Persoalan yang kontroversial meliputi definisi tipe hutan dalam moratorium ini, ruang lingkup atau kawasan moratorium dan kegiatan yang tidak tercakup dalam moratorium karena mendapat perkecualian.

\subsection{Menggunakan Definisi yang Membingungkan}

Organisasi Pangan dan Pertanian PBB (FAO) memberi definisi 'hutan primer' sebagai hutan yang terdiri dari pepohonan jenis asli yang tumbuh secara alami, tidak terdapat tanda-tanda yang jelas tentang adanya kegiatan manusia dan proses ekologis tidak terganggu secara nyata (FAO 2010a). Dalam beberapa hal, istilah 'hutan primer' menggambarkan hutan tua yang didominasi oleh jenis asli dan tidak terganggu oleh kegiatan manusia dalam jangka waktu lama.

Penggunaan istilah 'hutan alam primer' dalam teks Inpres moratorium akan menimbulkan sejumlah implikasi terhadap kebijakan yang menentukan keberhasilan moratorium, khususnya dalam menciptakan keadaan yang memungkinkan untuk mitigasi perubahan iklim. Berikut ini adalah alasan kenapa hal itu akan timbul.

Pertama, istilah 'hutan alam primer' belum pernah digunakan dalam kebijakan kehutanan di Indonesia. Menurut Kementerian Kehutanan, untuk alasan praktis, 'hutan alam primer' dimaksudkan untuk menyiratkan bahwa di wilayah tersebut belum pernah ada izin yang diterbitkan (Hadi Daryanto, Sekretaris Jenderal Kementerian Kehutanan, komunikasi pribadi 2011). Kementerian Kehutanan menggunakan istilah 'hutan primer', sebagaimana definisi FAO, untuk tujuan pelaporan. Laporan Indonesia kepada FAO menafsirkan istilah ini bagi hutan-hutan yang dicirikan oleh tiadanya jalan pembalakan pada citra pengindraan jauh, tanpa memperhatikan apakah hutan tersebut memiliki izin HPH (FAO 2010b). Ketika istilah 'hutan alam primer' digunakan dalam moratorium, yang berbeda dengan istilah yang digunakan dalam LoI ('hutan alam') maka akan terjadi perbedaan yang nyata dalam ruang lingkup moratorium.

Kedua, istilah yang digunakan dalam moratorium secara jelas tidak memasukkan hutan sekunder atau areal bekas tebangan, yang sebagian mungkin akan lebih baik jika dikelola sebagai hutan dibandingkan dengan dikonversi atau untuk penggunaan lainnya. Menurut Kementerian Kehutanan (2009), tahun 2009, Indonesia memiliki 45,2 juta ha hutan primer, 41,4 juta ha hutan sekunder di lahan hutan negara dan 5,3 juta ha kawasan hutan di luar lahan hutan negara, yang umumnya dianggap sebagai hutan sekunder.

Sangat disayangkan bahwa hutan sekunder yang luasnya mencakup lebih dari separuh luas kawasan hutan di Indonesia tidak dimasukkan ke dalam moratorium. Hutan sekunder memiliki cadangan karbon lebih tinggi dibandingkan perkebunan kelapa sawit atau hutan tanaman penghasil serat (Murdiyarso dkk. 2002). Dalam banyak hal, hutan tersebut juga memiliki keanekaragaman hayati yang lebih tinggi (Danielsen dkk. 2008, Koh dan Wilcove 2008). Dengan demikian, kegagalan untuk memasukkan hutan sekunder dan hutan yang tidak berada di bawah pengawasan Kementerian Kehutanan ke dalam moratorium ini merupakan hilangnya peluang untuk melindungi, paling sedikit untuk sementara, hutan seluas 46,7 juta ha yang masih kaya karbon dan keanekaragaman hayati.

\subsection{Memasukkan Hutan Lindung dan Hutan Konservasi yang Telah Dilindungi}

Hutan konservasi di Indonesia terdiri dari 313 cagar alam dengan luas rerata 30500 ha dan 168 kawasan konservasi dan taman nasional dengan luas rerata 70000 ha (Kementerian Kehutanan 2008). Hutan lindung ditetapkan terutama untuk melindungi fungsi-fungsi hidrologis karena terletak di daerah yang bergunung-gunung. Kawasan ini secara hukum sudah dilindungi, sehingga jika hukum ditegakkan, moratorium tidak akan memberikan pengaruh apapun terhadap cadangan karbon biomassa atau keanekaragaman hayati di kawasan ini. 
Kawasan konservasi dilindungi oleh UU No.

41/1999 dan peraturan pemerintah terkait. Namun, sampai dengan tahun 2007, penyerobotan hutan di kawasan ini terjadi dengan laju rerata $200000 \mathrm{ha} /$ tahun (Kementerian Kehutanan 2008). Penyerobotan hutan hanya dapat diselesaikan dengan penegakan hukum yang ada karena tidak mungkin bagi Inpres moratorium yang tanpa sanksi bagi pelanggar akan menyelesaikan masalah ini secara efektif.

Kawasan konservasi (KK) yang terdiri dari hutan konservasi dan hutan lindung, di pulau-pulau atau kepulauan disajikan pada Tabel 1. Ketika PIPIB disajikan menurut pulau, kita dapat menetapkan tumpang tindih antara KK dan PIPIB. Hasilnya menunjukkan bahwa daerah yang tercakup secara khusus dalam moratorium di masing-masing pulau utama di Indonesia lebih kecil dibandingkan dengan yang ditunjukkan pada PIPIB.

Penetapan daerah baru yang secara khusus tercakup dalam moratorium memungkinkan kita untuk memantau keberhasilan moratorium dan upaya pengurangan emisi selanjutnya di masingmasing pulau dan daerah administrasi lain. Selain itu, memisahkan daerah yang tercakup dalam moratorium dari daerah-daerah yang sudah termasuk kawasan konservasi akan memungkinkan untuk mengevaluasi cara penerapan moratorium di tingkat daerah dan untuk mengenali kemungkinan adanya pelanggaran.

\subsection{Membuat Pengecualian yang Berpotensi Menimbulkan Masalah Baru}

Pasal 2 Inpres 10/2011 memuat 4 pengecualian. Tiga pengecualian pertama kemungkinan akan bertentangan dengan pemenuhan sasaran pengurangan emisi. Bergantung pada seberapa bebas izin HPH diberikan, pengecualian ini berpotensi menimbulkan masalah baru dan melemahkan tujuan moratorium.

Pertama, Inpres ini mengecualikan hutan yang telah memperoleh 'izin prinsip' dari Menteri Kehutanan, tanpa memperhatikan kekayaan karbon, keanekaragaman hayati atau sejumlah jasa lingkungan lainnya.

Kedua, Inpres ini mengecualikan lahan yang dibutuhkan untuk proyek vital pembangunan nasional (panas bumi, minyak dan gas alam, listrik, padi dan tebu), tanpa memperhatikan kedekatan letaknya dengan kawasan konservasi. Kegiatan-kegiatan yang diperlukan untuk memenuhi kebutuhan listrik yang meningkat dapat ditafsirkan sebagai kesempatan mencakup peluasan penambangan batu bara. Misalnya, di Provinsi Kalimantan Tengah, eksplorasi dan eksploitasi batu bara sering berkaitan dengan hutan produksi yang memiliki izin HPH (lihat Kotak 1).

Tabel 1. Luas kawasan moratorium berdasarkan pulau (juta ha), sebagaimana ditunjukkan oleh perbandingan kawasan konservasi dan cakupan Peta Indikatif Penundaan Izin Baru.

\begin{tabular}{lcccc}
\hline Pulau & $\begin{array}{c}\text { Kawasan } \\
\text { konservasi yang } \\
\text { sudah dilindungi } \\
(\text { KK) }\end{array}$ & $\begin{array}{c}\text { Cakupan } \\
\text { moratorium } \\
\text { berdasarkan PIPIB }\end{array}$ & $\begin{array}{c}\text { Kawasan } \\
\text { tumpang tindih } \\
\text { antara KK } \\
\text { dan PIPIB }\end{array}$ & $\begin{array}{c}\text { Kawasan baru yang } \\
\text { sesungguhnya } \\
\text { dicakup moratorium }\end{array}$ \\
\hline $\begin{array}{l}\text { Bali, Nusa Tenggara } \\
\text { dan Maluku }\end{array}$ & 3,3 & 3,9 & 2,8 & 1,1 \\
Jawa & 1,0 & 1,2 & 0,8 & 0,4 \\
Kalimantan & 10,2 & 16,1 & 9,3 & 6,8 \\
Papua & 16,8 & 24,0 & 16,1 & 7,9 \\
Sulawesi & 6,1 & 7,0 & 5,6 & 1,4 \\
Sumatera & 10,5 & 14,1 & 9,2 & 4,9 \\
Indonesia (total) & 47,8 & 66,4 & 43,9 & $\mathbf{2 2 , 5}$ \\
\hline
\end{tabular}

a Sumber: Kementerian Kehutanan (2009) 
Kotak 1. Perubahan status lahan hutan di Kalimantan Tengah yang terjadi akhir-akhir ini

Peraturan Pemerintah No. 24/2010 mengizinkan HPH dipinjam-pakai untuk kegiatan penambangan sampai seluas $10 \%$ hutan produksi yang memiliki endapan mineral/batu bara. Larangan penambangan hanya berlaku untuk hutan konservasi; penambangan bawah tanah masih diizinkan di hutan lindung.

Pengaruh kebijakan ini terhadap emisi gas rumah kaca cukup besar. Kegiatan penebangan hutan akan mengambil sebagian biomassa di atas tanah dan seharusnya pulih ketika hutan tumbuh kembali, sehingga emisi neto menjadi lebih kecil. Akan tetapi dengan praktik penambangan terbuka, seluruh biomassa, baik di atas maupun di bawah tanah, dibersihkan sehingga lebih banyak emisi karbon dioksida per satuan luas lahan. Selanjutnya, laju pemulihan penyimpanan karbon dan akumulasi biomassa di lahan yang terdegradasi akibat penambangan juga rendah.

Sejak 2008, 39 buah izin pinjam-pakai telah diterbitkan untuk pertambangan di Kalimantan Tengah. Sebagian besar izin diterbitkan pada tahun 2010, tetapi tujuh di antaranya diterbitkan pada tahun 2011 sebelum Inpres No. 10/2011 diundangkan. Secara keseluruhan, izin ini mencakup lahan seluas 161502 ha, 8895 ha di antaranya dialokasikan untuk pertambangan pada tahun 2011.

Penundaan dalam penandatanganan moratorium menimbulkan keprihatinan masyarakat luas terkait dengan integritas Inpres ini karena banyak izin yang tampaknya diterbitkan terburu-buru selama lima bulan antara Januari sampai Mei 2011. Kenyataan bahwa moratorium ini tidak berlaku surut, yaitu sejak 1 Januari 2011, sesuai rencana semula, telah menguntungkan pihak yang memanfaatkan peluang untuk memperoleh izin HPH dalam jangka waktu tersebut.

Sebelas hari setelah moratorium diberlakukan, Keputusan Menteri baru (SK 292/Menhut II/2011) diterbitkan. SK ini mengubah status hampir 1,2 juta ha lahan hutan negara menjadi lahan untuk penggunaan lain dan memberlakukan hal yang sebaliknya, tetapi hanya mencakup 30000 ha lahan nonhutan yang dikategorikan ulang sebagai lahan hutan. Semua perubahan ini terjadi di Kalimantan Tengah, yang baru-baru ini terpilih sebagai provinsi uji-coba REDD+ berdasarkan Lol.

Sejumlah pengecualian dalam pelaksanaan moratorium nampaknya terkait dengan Inpres No. 5/2011 tentang ketahanan pangan, yang memerintahkan:

1. Menteri Pertanian untuk memperluas luas wilayah produksi pangan;

2. Menteri Kehutanan untuk mengizinkan penggunaan lahan hutan bagi tujuan produksi pangan; dan

3. Menteri Pekerjaan Umum untuk membangun prasarana guna mendukung produksi dan pengangkutan beras.

Di Papua, lebih dari 1 juta ha lahan yang dialokasikan untuk dikonversi menjadi sawah dan kebun tebu sebagai bagian dari Lumbung Pangan dan Energi Terpadu Merauke dapat dikecualikan dari moratorium ini.
Ketiga, Inpres No. 10/2011 tidak melarang perpanjangan masa izin HPH yang ada untuk eksploitasi hutan dan/atau penggunaan kawasan hutan selama izin usaha tersebut masih berlaku, tanpa memperhatikan kinerja pemegang izin dalam kaitannya dengan ketentuan yang berlaku, termasuk integritasnya terhadap masalah sosial dan lingkungan.

Sebaliknya, pengecualian ke empat - untuk rehabilitasi ekosistem - berpeluang cukup baik karena menciptakan kesempatan baru untuk meningkatkan cadangan karbon melalui penghutanan/reboisasi. Izin restorasi ekosistem (RE) akan memberikan hak kepada pemegang HPH-RE atas lahan hutan selama 65 tahun dengan kemungkinan perpanjangan 35 tahun. Jenis pengaturan ini dapat membantu mengatasi persoalan kesinambungan apabila lahan akan dikembangkan untuk pendanaan REDD+. 


\section{Kemungkinan Dampak Moratorium}

\subsection{Dampak Lingkungan}

Lahan gambut mendapat perhatian khusus dalam moratorium karena peran pentingnya dalam menyimpan karbon dan menyediakan jasa lingkungan lain, termasuk konservasi air dan keanekaragaman hayati. Sesungguhnya, dampak lingkungan positif utama dari moratorium adalah dari perlindungan tambahan yang diberikan kepada ekosistem ini.

Lahan gambut Indonesia seluas sekitar 20,2 juta ha, tersebar di Sumatera, Kalimantan dan Papua dengan kedalaman dan massa jenis berbeda-beda. Lahan ini diperkirakan menyimpan lebih dari 30 miliar ton karbon (Kementerian Kehutanan 2008). Papua memiliki lahan gambut terluas meskipun kebanyakan dangkal. Sebaliknya, Kalimantan memiliki luas gambut terkecil, tetapi tergolong dalam, sangat dalam dan amat sangat dalam, sebagaimana disajikan pada

Tabel 2.
(6,2 juta ha tercakup dalam moratorium dan 3,3 juta ha tidak tercakup dalam moratorium), menghadapi risiko terbesar untuk terdegradasi lebih lanjut, yang diikuti oleh hutan bekas tebangan di lahan gambut yang seluas 5,4 juta ha $(3,9$ juta ha dalam cakupan moratorium dan 1,5 juta ha tidak tercakup dalam moratorium). ${ }^{16}$

Sebagian besar lahan gambut dalam di Sumatera berada di Provinsi Riau, sedang di Kalimantan berada di Kalimantan Tengah. Dua provinsi ini berturutturut memiliki 19,4\% dan 14,9\% dari luas lahan gambut keseluruhan di Indonesia (Gambar 2a, 2b, $2 \mathrm{c}$ dan $2 \mathrm{~d}$ ). Selain itu, provinsi-provinsi ini memiliki lahan gambut tak berhutan yang luas. Oleh karena itu, pelaksanaan moratorium dan revisi PIPIB semestinya mengutamakan perlindungan terhadap hutan gambut dan lahan gambut bekas tebangan yang berada dalam kewenangan Kementerian Kehutanan, dengan perhatian khusus terhadap dua provinsi ini.

Tabel 2. Sebaran lahan gambut menurut kedalaman di tiga pulau utama di Indonesia (dalam ribu ha)

\begin{tabular}{|c|c|c|c|c|c|c|c|}
\hline Pulau & $\begin{array}{l}\text { Sangat } \\
\text { dangkal } \\
(<50 \mathrm{~cm})\end{array}$ & $(50-100 \mathrm{~cm})$ & $(100-200 \mathrm{~cm})$ & $(200-400 \mathrm{~cm})$ & $\begin{array}{c}\begin{array}{c}\text { Sangat } \\
\text { dalam }\end{array} \\
(400-800 \mathrm{~cm})\end{array}$ & $\begin{array}{c}\text { Amat sangat } \\
\text { dalam } \\
(>800 \mathrm{~cm})\end{array}$ & Jumlah \\
\hline Sumatera & 675 & 1236 & 2253 & 1234 & 1698 & - & 7097 \\
\hline Kalimantan & 183 & 1727 & 1387 & 1105 & 1061 & 279 & 5743 \\
\hline Papua & 174 & 4923 & 650 & 1683 & - & - & 7431 \\
\hline Total & 1032 & 7887 & 4291 & 4021 & 2759 & 279 & 20270 \\
\hline
\end{tabular}

Sumber: Wetlands International (2003, 2004, 2006)

Kepadatan karbon di lahan gambut berhutan dapat mencapai 5-10 kali lipat dibandingkan dengan tanah mineral berhutan dalam satuan luas yang sama, bergantung pada kedalaman gambutnya. Oleh karena itu, melindungi lahan gambut merupakan upaya nyata dalam hal pengurangan emisi dan manfaat lingkungan lainnya. Namun hanya 4,2 juta ha gambut yang tercakup dalam moratorium masih berada di dalam tutupan hutan primer. Bergantung pada pengendalian kebakaran hutan dan perubahan tata air dari lahan gambut yang terganggu, emisi karbon dioksida $\left(\mathrm{CO}_{2}\right)$ akan terus berlanjut sekalipun moratorium membatasi kerusakan lebih jauh terhadap hutan yang tumbuh di atasnya. Lahan gambut yang tidak berhutan seluas 9,5 juta ha
Laju deforestasi di lahan gambut berhutan selama 2000-2005 adalah sekitar 100000 ha per tahun. Sebagian besar gambut dalam yang telah gundul dan rusak terletak di Provinsi Riau (Kementerian Kehutanan 2008). Kajian terbaru menunjukkan bahwa laju deforestasi di hutan gambut di Asia Tenggara kepulauan (terutama Indonesia) selama 2000-2010 sebesar 2,2\% per tahun, jauh lebih tinggi dari laju deforestasi tahunan di hutan hujan dataran rendah sebesar 1,2\% (Miettinen dkk. 2011).

16 Untuk informasi lebih lanjut, lihat: Lawrence, D. 2011 Indonesia's forest moratorium: analyzing the numbers. http://blog.cifor.org/3272/indonesia\%E2\%80\%99s-forestmoratorium $\% \mathrm{E} 2 \% 80 \% 94$ analyzing-the-numbers/. 


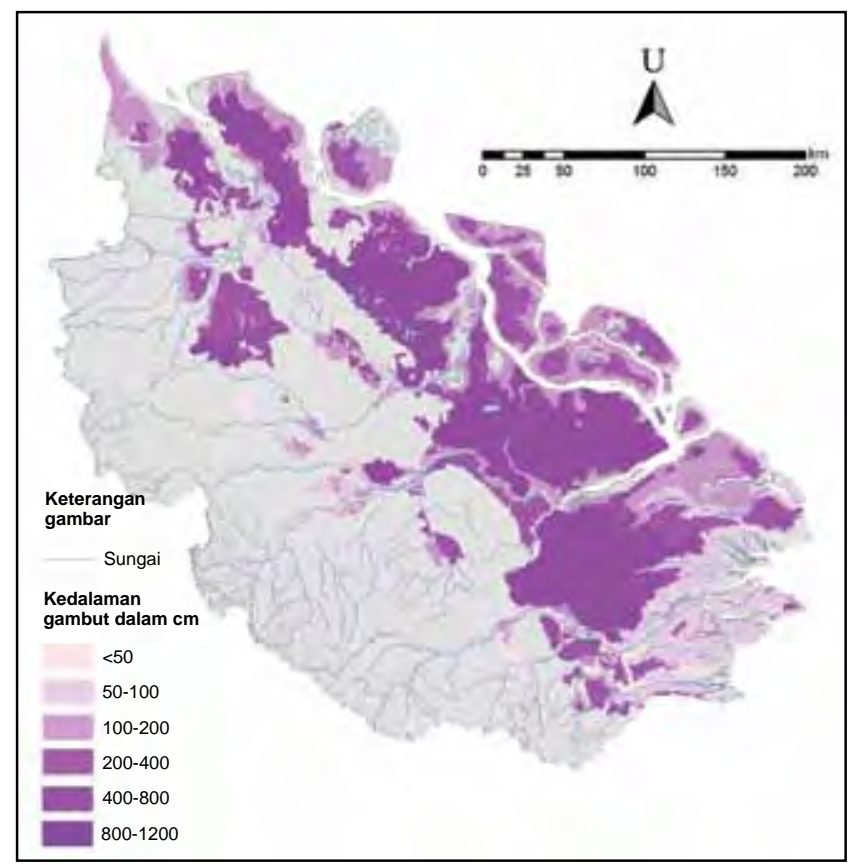

Gambar 2a. Sebaran lahan gambut menurut kedalaman di Provinsi Riau

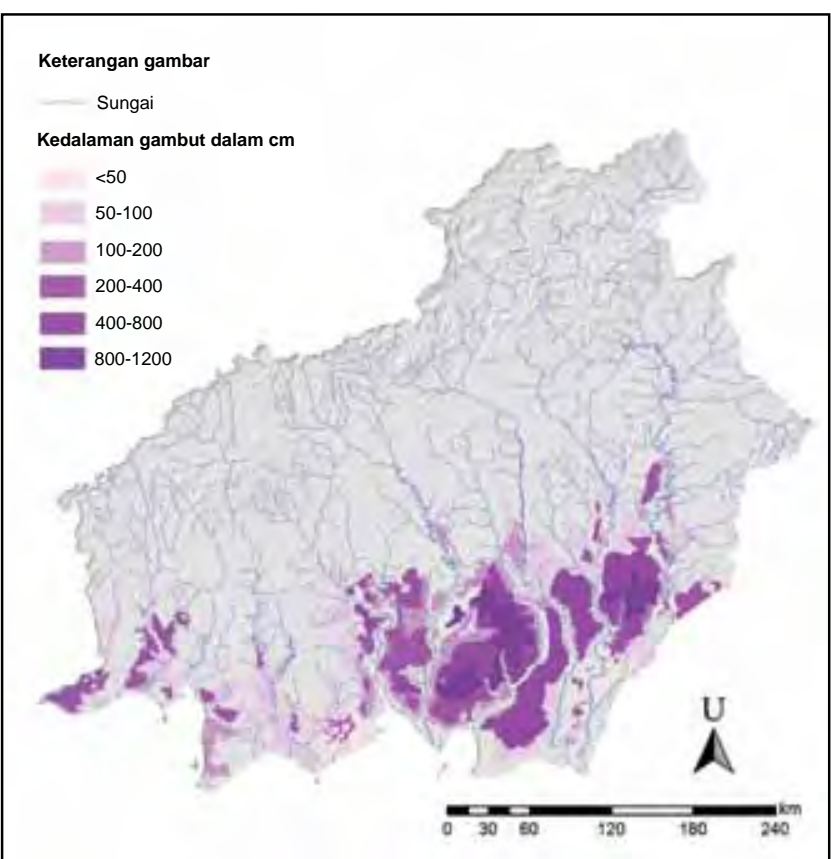

Gambar 2c. Sebaran lahan gambut menurut kedalaman di Provinsi Kalimantan Tengah

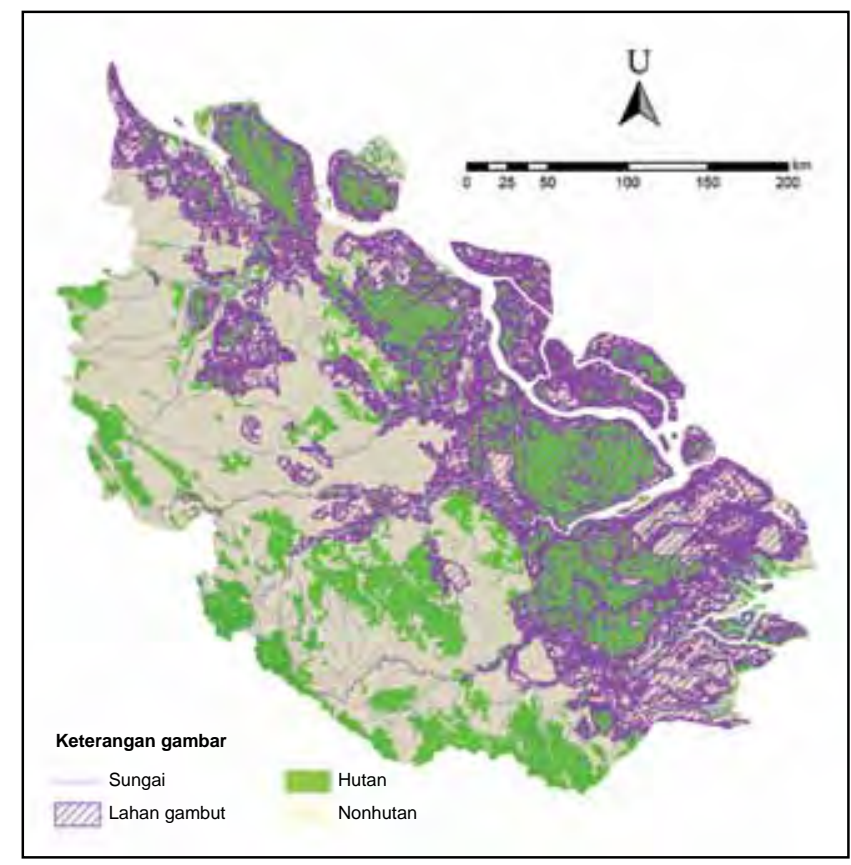

Gambar 2b. Sebaran gambut menurut kedalaman yang ditumpangtindihkan dengan kawasan hutan di Provinsi Riau

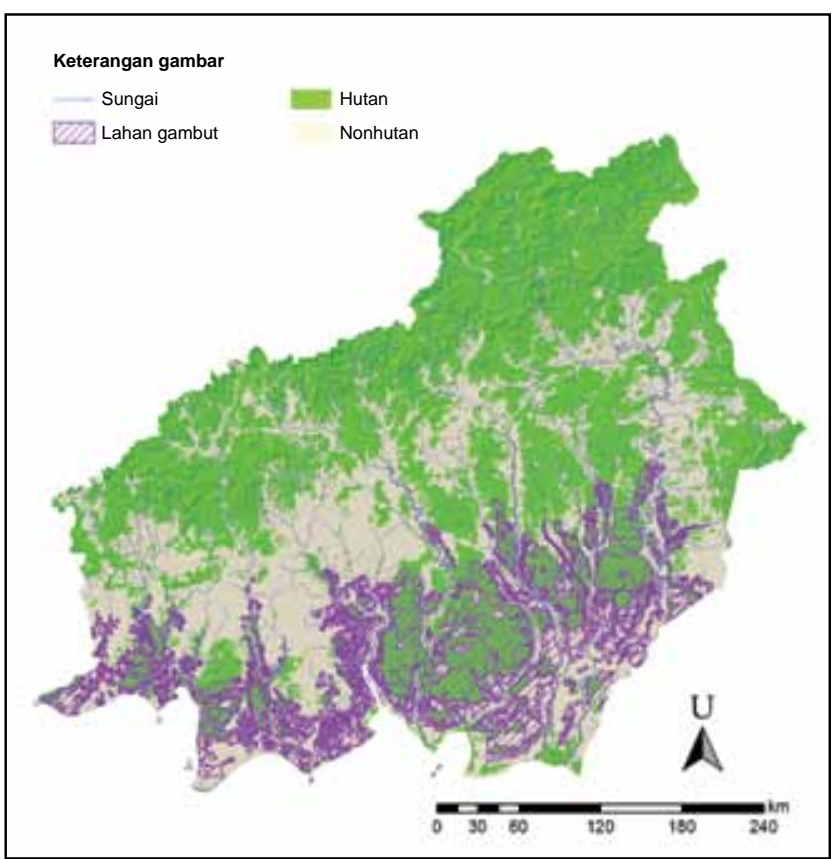

Gambar 2d. Sebaran lahan gambut menurut kedalaman yang ditumbangtindihkan dengan kawasan hutan di Provinsi Kalimantan Tengah

Sumber: Wetlands International (2006) dan Kementerian Kehutanan (2011) 
Dengan laju kerusakan yang demikian tinggi akibat konversi yang berlanjut dengan drainase, kebakaran, pemadatan dan oksidasi gambut, menghindari konversi lahan gambut dangkal pun akan mengurangi emisi $\mathrm{CO}_{2}$ dan gas rumah kaca lainnya dalam jumlah yang sangat berarti.

Pengeringan lahan gambut dapat menyebabkan kubah gambut runtuh dan emisi gas rumah kaca meningkat. Di daerah pesisir, runtuhnya gambut telah menyebabkan intrusi air laut sehingga memaksa petani pindah dari lahan pertanian mereka (Joshi dkk. 2010). Dampak langsung akibat kesalahan pengelolaan lahan gambut ini menimbulkan tantangan baru dalam hal penghidupan masyarakat yang melampaui persoalan perubahan iklim.

Emisi $\mathrm{CO}_{2}$ dari konversi lahan gambut menjadi perkebunan kelapa sawit mencapai sekitar 60 ton/ ha/th (Murdiyarso dkk. 2010, Hergoualc'h dan Verchot 2011). Namun lahan gambut akan terus mengemisikan gas rumah kaca meskipun kegiatan konversi telah berhenti. Seandainya moratorium ditujukan untuk melindungi seluruh lahan gambut, tanpa memperhatikan kedalaman dan jenis tutupan hutan, bahkan melindungi lahan gambut yang tak berhutan sekalipun maka penurunan emisi karbon akan sangat besar.

Walaupun secara kelembagaan cukup menantang, pengembangan dan pelaksanaan proyek REDD+ pada lahan gambut yang telah dikelola nampaknya merupakan pilihan yang akan membawa dampak besar dan positif terhadap lingkungan. Pengurangan emisi dari lahan gambut melibatkan pengelolaan air yang sangat ketat (untuk menyeimbangkan emisi dan produktivitas sistem) dan pengendalian kebakaran (untuk memastikan terjaganya biomassa baik di atas maupun di bawah permukaan tanah). Untuk mendukung pengelolaan lahan gambut yang berkesinambungan diperlukan penyempurnaan tata kelola lahan gambut, termasuk memperjelas sistem pemilikan atau penguasaan lahan, peningkatan kapasitas dan penegakan hukum.

\subsection{Dampak Ekonomi}

Pemegang HPH dan pengusaha perkebunan kelapa sawit khawatir bahwa moratorium akan mengancam penyediaan lapangan kerja karena dapat mengganggu program peluasan mereka. Keabsahan klaim seperti ini perlu dicermati.

Menurut telaah Reuters, perusahaan-perusahaan perkebunan besar kelapa sawit yang beroperasi di Indonesia telah melakukan peluasan dengan laju 10000 ha per perusahaan per tahun (Koswanage dan Taylor 2011). Bagi perusahaan-perusahaan ini, penguasaan lahan terkecil sekalipun cukup bagi mereka untuk meneruskan peluasan selama dua tahun ke depan. Perusahaan-perusahaan besar diduga telah menguasai lahan dalam jumlah yang cukup, dengan izin ataupun izin prinsip sehingga masih memungkinkan mereka melakukan peluasan dengan laju tersebut hingga jauh melampaui jangka waktu dua tahun moratorium. Jika temuan dalam laporan Reuters benar, moratorium berdampak minimal terhadap lapangan kerja yang berkaitan dengan peluasan kebun sawit.

Moratorium dua tahun justru dapat dimanfaatkan pengembang untuk menggeser kegiatan mereka dari peluasan lahan produksi prioritas menjadi peningkatan produksi dari kebun yang ada. Produktivitas per satuan luas pada kebanyakan perkebunan kelapa sawit di Indonesia jauh lebih rendah dibandingkan potensinya. Rerata produktivitas minyak sawit saat ini adalah 3,5 ton per ha, yaitu $40 \%$ lebih rendah daripada rerata produksi Malaysia sebesar 6,4 ton per ha (KPPU 2007). Pilihan untuk meningkatkan produktivitas dapat dibuat sambil memperbaiki prasarana, yang dengan sendirinya menciptakan lapangan pekerjaan dan menghasilkan pendapatan tambahan bagi masyarakat setempat.

Perusahaan juga dapat merehabilitasi ekosistem pada hutan gambut yang terdegradasi dan telah dikuasainya. Walaupun cadangan karbon di atas permukaan tanah di daerah ini mungkin rendah, karbon di bawah tanahnya masih tinggi. Perusahaan-perusahaan ini harus didorong untuk mengajukan izin baru bagi rehabilitasi ekosistem yang dikecualikan dalam Inpres moratorium ini. Jika skema seperti ini laik secara ekonomis maka tidak tertutup kemungkinan menarik investasi sektor swasta. 


\section{Melangkah ke Depan dengan Keterbukaan}

Data tutupan lahan 2009 dan PIPIB yang diumumkan oleh Kementerian Kehutanan untuk diketahui masyarakat pada bulan Agustus 2011 merupakan langkah penting yang perlu dihargai. Mengingat moratorium memiliki rentang waktu yang pendek dan cakupan areal yang terbatas, salah satu instruksi terpenting Inpres ini ialah memerintahkan kementerian dan lembaga lainnya untuk melakukan dialog secara terbuka dan rutin dengan masyarakat untuk menyempurnakan peta tersebut.

Salah satu butir moratorium menyatakan bahwa PIPIB akan selalu direvisi secara rutin setiap enam bulan. Hal ini mengisyaratkan bahwa proses paduserasi antara PIPIB, izin HPH dan tata ruang baik di tingkat kabupaten maupun provinsi dapat dilakukan. Dengan demikian cakupan kawasan moratorium akan lebih luas dan lebih pasti secara hukum. Tata kelola sumber daya lahan dan hutan juga secara hukum akan lebih baik dan target pengurangan emisi dapat lebih terjamin.

Walaupun pelaksanaan Inpres ini merupakan tanggung jawab bersama, Kementerian Kehutanan akan memimpin, khususnya dalam hal revisi peta. Apabila daerah yang tercakup dalam moratorium perlu diperluas, Kementerian Kehutanan juga dapat meninjau ulang izin prinsip yang telah disetujui maupun mempertimbangkan perpanjangan masa izin yang ada.

Keterlibatan banyak lembaga pemerintah dan pemangku kepentingan merupakan tantangan tersendiri; koordinasi antara pemerintah pusat dan daerah belum pernah mulus. Menafsirkan undangundang desentralisasi untuk menjelaskan landasan peraturan bagi pelaksanaan desentralisasi di tingkat makro, khususnya sektor kehutanan, merupakan perjuangan panjang (Barr dkk. 2006). Akan tetapi, mengingat besarnya manfaat yang ditawarkan moratorium kesempatan ini harus dimanfaatkan.

Mengingat kemampuannya dalam menyimpan karbon, konservasi lahan gambut perlu diutamakan dengan pendekatan strategis untuk menghadapi tantangan baru yang akan timbul. Amanat Inpres dan
PIPIB mengisyaratkan bahwa perlindungan lahan gambut dapat diandalkan untuk mengurangi emisi karbon yang berbasis lahan. Dalam kaitannya dengan lahan gambut, Badan Perencanaan Pembangunan Nasional (Bappenas 2009) telah mengusulkan tiga skenario kebijakan yang sesuai sebagai berikut:

1. Pemenuhan terhadap ketentuan hukum dan praktik pengelolaan terbaik di lahan produksi yang ada,

2. Rehabilitasi lahan gambut dan pencegahan kebakaran yang tidak terkendali,

3. Revisi alokasi lahan, konservasi hutan dan tukarguling antar lahan.

Pendekatan bentang alam cukup tepat untuk mengatasi persoalan tata ruang dan penggunaan lahan gambut. Akan tetapi, sebagian lahan gambut penggunaannya berada dalam kewenangan kementerian yang tidak dilibatkan dalam pelaksanaan moratorium (Pertanian dan Energi dan Sumberdaya Mineral). Kewenangan, pertanggunggugatan dan pertanggungjawaban pengelolaan yang jelas untuk seluruh lahan gambut perlu ditetapkan.

Proses peninjauan secara terbuka sebaiknya diselaraskan dengan bentuk perizinan 'pinjam-pakai' yang ada. Dalam rangka pembangunan rendah emisi, izin bagi kegiatan ekonomi dalam ekosistem kaya karbon seperti lahan gambut dapat dialihkan ke daerah tak berhutan (41 juta ha di hutan negara saja). Demikian juga, tukar-guling lahan antara daerah berkarbon tinggi dan rendah dalam 6,2 juta ha hutan dengan Areal untuk Penggunaan Lain (APL) maupun antara APL dan lahan hutan yang telah terdegradasi perlu didorong untuk mencapai tujuan pembangunan berkelanjutan.

Di luar ketentuan Inpres, terdapat banyak potensi untuk menerapkan REDD+ di Indonesia, meskipun hanya di dalam kawasan hutan primer dan lahan gambut. Namun berdasarkan Peraturan Menteri tentang Rencana Kehutanan Nasional, ${ }^{17}$ hanya 5,5 juta ha hutan alam dan lahan gambut akan dilindungi sampai dengan 2030, yang jauh lebih kecil dibandingkan dengan daerah PIPIB sekarang. Tanpa tindakan terencana bagi kawasan yang sekarang

17 Peraturan Menteri No. P. 49/Menhut II/2011 tentang Rencana Kehutanan Nasional 2011-2030. 
tercakup dalam PIPIB tetapi tidak dialokasikan untuk perlindungan dalam jangka waktu lebih lama (melampaui moratorium dua tahun), program REDD + akan menghadapi tantangan yang besar untuk mencapai sasaran pengurangan emisi pada tahun 2020. Jika tukar-guling lahan layak secara teknis maupun ekonomi, maka emisi dari hutan primer dan lahan gambut yang sangat besar akan dapat dikurangi.

Meskipun bukan satu-satunya, mengaitkan moratorium dengan pelaksanaan REDD+ adalah salah satu langkah untuk mencapai sasaran perlindungan hutan dan lahan gambut. Selanjutmya pengurangan emisi serta pemanfaatan pendanaan yang tersedia dari mekanisme pasar karbon perlu dipelajari. Untuk itu diperlukan analisis lebih lanjut terhadap aspek pendanaan ini, termasuk biaya langsung dan tidak langsung.

Beberapa peluang untuk meningkatkan manfaat moratorium disajikan pada Gambar 3. Upaya Kementerian Kehutanan dalam menyediakan data tutupan lahan tahun 2009 bagi masyarakat (digambarkan dengan buah yang di tangan). Tindakan ini idealnya diikuti dengan penyebaran informasi mengenai perizinan yang lebih lengkap, cermat dan mutakhir, peta penetapan hutan dan peta tata guna lahan. Dengan demikian masyarakat luas dapat terus berpartisipasi.

Masyarakat juga dapat membantu memberikan koreksi terhadap kesalahan klasifikasi dan memperbarui peta lama semestinya menghasilkan zonasi ulang kawasan gambut yang belum diterbitkan izinnya agar dilindungi. Demikian juga untuk kawasan hutan alam primer pada tanah mineral yang tidak diterbitkan izinnya (buah di cabang terendah).

Peninjauan ulang atas izin yang ada semestinya menjadi bagian dari proses revisi, yang dimulai dengan izin prinsip yang telah disetujui. Izin prinsip yang telah disetujui untuk lahan yang tinggi karbon (gambut) dan keanekaragaman hayatinya (hutan primer) di semua daerah seharusnya ditinjau ulang sebelum diberikan persetujuan akhir. Izin untuk kegiatan yang sedang berjalan perlu dievaluasi kepatuhannya pada peraturan yang berlaku, termasuk peraturan terkait dengan lingkungan dan upaya penurunan emisi. Kegiatan yang berkinerja buruk perlu ditangguhkan dan izin untuk kegiatan yang tidak mematuhi peraturan perlu dicabut (lihat empat buah di cabang tingkat kedua).

Memperluas ruang lingkup moratorium merupakan peluang yang perlu diperjuangkan juga, walaupun lebih sulit dicapai (lihat cabang paling tinggi).

Merevisi PIPIB dengan memasukkan hutan sekunder atau hutan bekas tebangan akan menjadi langkah berikutnya - pertama untuk hutan di lahan gambut, lalu hutan pada tanah mineral. Kawasan hutan dengan nilai konservasi tinggi (HNKT) untuk keanekaragaman hayati, perlindungan DAS dan jasa lingkungan lainnya perlu diutamakan. 'Hutan sekunder dan hutan alam yang tidak ditebang-habis mencakup kawasan yang sudah dan yang belum berada di bawah $\mathrm{HPH}$.

Analisis Mengenai Dampak Lingkungan (AMDAL) untuk semua kegiatan pembangunan di lahan gambut yang dapat menyebabkan dampak merugikan besar bagi lingkungan hidup semestinya merupakan bagian yang tidak terpisahkan dari proses peninjauan ulang. Sebaliknya, kegiatan seperti restorasi ekosistem mungkin hanya memerlukan Upaya Pengelolaan Lingkungan (UKL) dan Upaya Pemantauan Lingkungan (UPL).

Inpres moratorium ini jelas memerlukan kebijakan dan tindakan guna menyempurnakan tata kelola hutan. PIPIB yang direvisi setiap enam bulan untuk menunjukkan perkembangan dan hambatan pelaksanaan di lapangan perlu melibatkan masyarakat luas. Proses peninjauan ulang ini juga memungkinkan untuk mempertimbangkan peluang baru guna mencapai tujuan dasar moratorium: memperbaiki keadaan untuk pengelolaan hutan berkelanjutan. Sehingga akan memperlambat konversi hutan yang memiliki cadangan karbon dan keanekaragaman hayati tinggi. Pada saat yang sama penyempurnaan peraturan dan perundangundangan yang ada dan pembuatan peraturan baru juga dimungkinkan. Semua langkah ini diperlukan untuk meningkatkan tata kelola hutan. Sejumlah saran mengenai cara penggunaan moratorium untuk meningkatkan tata kelola hutan disajikan pada Kotak 2. 


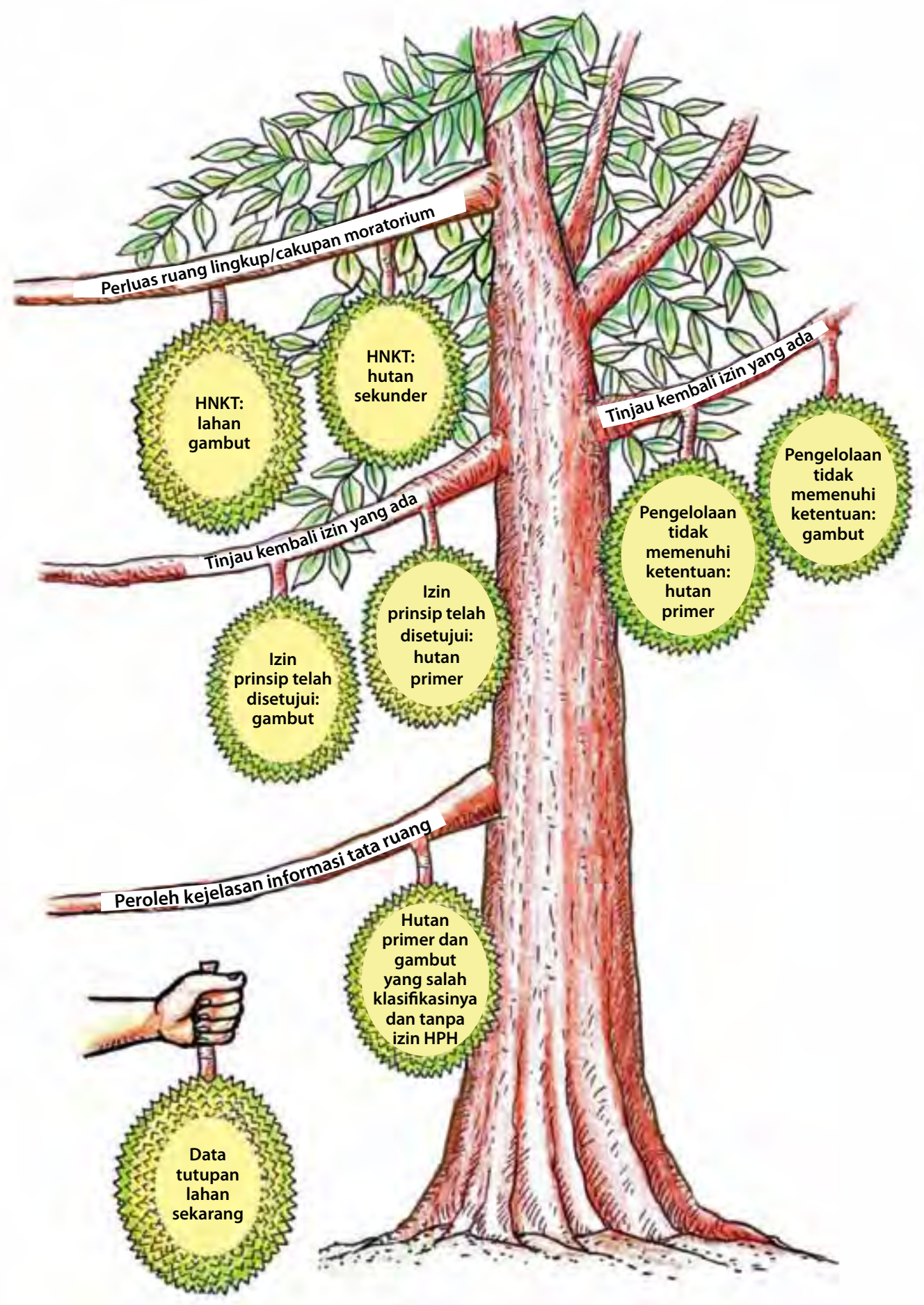

Gambar 3. Peluang untuk meningkatkan manfaat moratorium, dengan urutan sesuai tingkat kesulitannya

Tantangan yang akan dihadapi moratorium hutan akan berlangsung lebih lama daripada masa berlakunya moratorium. Pemerintah Indonesia perlu memanfaatkan moratorium untuk membentuk lembaga yang memiliki kemampuan memadai untuk mengatasi tantangan-tantangan ini. Lembaga ini semestinya memiliki sumber daya manusia dan anggaran yang memadai untuk mendukungnya, terlepas dari bentuk lembaganya. Lembaga Ini semestinya juga memiliki kewenangan hukum yang kuat untuk mengkoordinasikan beragam kegiatan dari berbagai pemangku kepentingan di berbagai tingkat. 


\section{Kotak 2. Pemanfaatan moratorium untuk meningkatkan tata kelola hutan}

Guna menyempurnakan ruang lingkup moratorium hutan selama dua tahun, disarankan agar lembagalembaga yang dilibatkan mengawasi revisi PIPIB dengan langkah-langkah berikut:

- Meninjau kembali 'izin prinsip yang telah disetujui' untuk hutan primer dan lahan gambut. Mengevaluasi keabsahan izin dan membuat proses peninjauan ulang dan penerbitan izin terbuka bagi masyarakat luas.

- Memeriksa kinerja perusahaan pemegang izin yang sedang berjalan dengan menggunakan kriteria dan indikator untuk perpanjangan masa izin. Selain persyaratan hukum, manfaat karbon, keanekaragaman hayati dan sosial juga perlu dipertimbangkan.

- Memasukkan hasil pemeriksaan ke dalam PIPIB setiap 6 bulan melalui cara yang menyeluruh dan terbuka, termasuk penetapan pilihan untuk melakukan tukar-guling lahan yang sah.

- Meminta masukan dari semua pemangku kepentingan, termasuk masyarakat umum, selama proses revisi PIPIB.

Inpres No. 10/2011 bukan merupakan tujuan, melainkan alat yang memungkinkan tata kelola hutan yang lebih baik melalui proses koordinasi, pengumpulan data dan kemungkinan, peraturan baru yang diperlukan. Dengan beberapa bulan sisa waktu moratorium, diperlukan penyusunan rencana yang konkret untuk:

- Mengenali kesenjangan data dan peraturan dalam perencanaan tata kelola hutan dan bentang alam dan menyusun strategi dan rencana untuk mengisi kesenjangan tersebut;

- Menetapkan indikator keberhasilan, proses penyempurnaan perencanaan tata kelola hutan dan bentang alam serta tata cara pelaksanaannya;

- Mempercepat perencanaan tata kelola hutan dan bentang alam dengan menggunakan pendekatan baru, kapasitas yang telah ditingkatkan dan peraturan yang diperbaiki, didukung oleh kelembagaan yang kuat.

\section{Kesimpulan}

Walaupun terbatas dalam hal waktu dan cakupan areal, moratorium ini berpotensi untuk mendukung perbaikan tata kelola hutan, yang merupakan penentu untuk mencapai pengurangan emisi berbasis lahan dalam jangka panjang.

Moratorium memberikan pesan yang jelas dan tegas mengenai pentingnya melindungi lahan gambut khususnya; menerjemahkan pesan Inpres ini dalam bentuk tindakan nyata akan mendorong pengurangan emisi dalam jumlah sangat besar. Namun demikian, Inpres ini tidak menetapkan sanksi sehingga dalam pelaksanaannya masih tetap menghadapi tantangan.

Arah yang diberikan dalam Inpres untuk hutan nongambut dapat dikategorikan sebagai kesempatan yang hilang. Revisi selama proses pelaksanaan masih memberi kesempatan kedua untuk mengalihkan pembangunan ke luar dari lahan berkarbon tinggi, termasuk hutan sekunder yang tidak dapat dikategorikan sebagai hutan alam primer, yang sejalan dengan strategi pemerintah untuk kegiatan pembangunan beremisi rendah.

Pemaduan rencana tata ruang pada tingkat provinsi dan kabupaten untuk menghasilkan revisi PIPIB secara berkala akan menuntut kepemimpinan yang tegas, keterbukaan dan pendekatan partisipatif.

Moratorium semestinya tidak dipandang sebagai tujuan untuk mencapai sasaran pengurangan emisi seperti yang dicanangkan Presiden. Moratorium adalah alat untuk menciptakan keadaan yang memungkinkan perbaikan tata kelola hutan dan lahan gambut, yang diperlukan untuk menunjang strategi pembangunan berkarbon rendah dan keikutsertaan dalam mekanisme global seperti REDD+ dalam jangka panjang. Moratorium dapat membuka jalan bagi keberhasilan pembaruan kebijakan jauh melampaui masa berlakunya yang hanya dua tahun. 


\section{Daftar Pustaka}

Badan Perencanaan dan Pembangunan Nasional (Bappenas) 2009 Reducing carbon emissions from Indonesia's peat lands. Interim report of a multidisciplinary study. Bappenas, Jakarta, Indonesia.

Barr, C., Resosudarmo, I.A.P., Dermawan, A., McCarthy, J.F., Moeliono, M. dan Setiono, B. 2006 Implications for forest sustainability, economic development and community livelihoods. CIFOR, Bogor, Indonesia.

Danielsen, F., Beukema, H., Burgess, N.D., Parish, F., Brühl, C., Donald, P.F., Murdiyarso, D., Phalan, B., Reijnders, L., Struebig, M. dan Fitzherbert, E.M. 2008 Biofuel plantations on forested lands: double jeopardy for biodiversity and climate. Conservation Biology 23: 348-358.

Food and Agriculture Organization (FAO) 2010a Global forest resources assessment. Laporan utama. FAO Forest Paper No. 163. FAO, Roma.

Food and Agriculture Organization (FAO) 2010b Global forest resources, country report: Indonesia. FAO, Roma.

Hergoualc'h, K. dan Verchot, L.V. 2011 Stocks and fluxes of carbon associated with land use change in Southeast Asian tropical peatlands: a review. Global Biogeochemical Cycles 25: GB2001. doi: 10.1029/2009GB003718.

Joshi, L., Janudianto, van Noordwijk, M. dan Pradhan, U.P. 2010 Investment in carbon stocks in the eastern buffer zone of Lamandau River Wildlife Reserve, Central Kalimantan province, Indonesia: a REDD+ feasibility study. Laporan proyek. World Agroforestry Centre, Bogor, Indonesia. http://www.worldagroforestry.org/ sea/publication?do=view_pub_detail\&pub_ no=RP0268-11 (10 October 2011).

Kementerian Kehutanan 2008 Consolidation report. Reducing emissions from deforestation and forest degradation in Indonesia. Kementerian Kehutanan, Jakarta, Indonesia.

Kementerian Kehutanan 2009 Forest designation map. Kementerian Kehutanan, Jakarta, Indonesia.
Kementerian Kehutanan 2011 Digital forest cover map. Kementerian Kehutanan, Jakarta, Indonesia (tidak diterbitkan).

Koh, L.P. dan Wilcove, D.S. 2008 Is oil palm agriculture really destroying tropical biodiversity? Conservation Letters 1: 60-64. doi: 10.1111/j.1755-263X.2008.00011.x.

Komisi Pengawas Persaingan Usaha (KPPU) 2007 Evaluation of national oil palm policy. KPPU, Jakarta, Indonesia.

Koswanage, N. dan Taylor, M. 2011 Land banks buffer Indonesian palm oil from forest ban.

Reuters, 25 Mei. http://www.reuters.com/ article/2011/05/25/us-indonesia-palmoilforests-idUSTRE74O2LA20110525 [17 October 2011].

Miettinen, J, Shi, C.H. dan Liew, S.C. 2011 Deforestation rates in insular Southeast Asia between 2000 and 2010. Global Change Biology 17: 2261-2270.

Murdiyarso, D., van Noordwijk, M., Wasrin, U.R., Tomich, T.P. dan Gillison, A. 2002 Environmental benefits and sustainable land-use in Jambi transect, Sumatra, Indonesia. Journal of Vegetation Science 13: 429-438.

Murdiyarso, D., Hergoualc'h, K. dan Verchot, L.V. 2010 Opportunities for reducing greenhouse gas emissions in tropical peatlands. Proceedings of the National Academy of Sciences USA 107:19655-19660.

Wells, P. dan Paoli, G. 2011 An analysis of Presidential Instruction No. 10, 2011: moratorium on granting of new licences and improvement of natural primary forest and peatland governance. Daemeter Consulting, Bogor, Indonesia.

Wetlands International 2003 Maps of peatland distribution and carbon content in Sumatra, 1990-2002. Wetlands International, Bogor, Indonesia.

Wetlands International 2004 Maps of peatland distribution and carbon content in Kalimantan, 2000-2002. Wetlands International, Bogor, Indonesia.

Wetlands International 2006 Maps of peatland distribution and carbon content in Papua, 2000 2002. Wetlands International, Bogor, Indonesia. 


Pada tanggal 20 Mei 2011, Pemerintah Indonesia menerbitkan Instruksi Presiden No. 10/2011 tentang penundaan penerbitan izin baru dan penyempurnaan tata kelola hutan alam primer dan lahan gambut, sebagai bagian dari kerjasama Indonesia dengan Pemerintah Kerajaan Norwegia, berdasarkan Surat Pernyataan Kehendak yang ditandatangani oleh kedua pemerintah pada tanggal 26 Mei 2010. Inpres yang menetapkan moratorium selama dua tahun terhadap izin hak pengusahaan hutan baru tersebut, menimbulkan wacana publik yang luas dan akan mempengaruhi kebijakan publik yang terkait. Makalah ini menganalisis makna moratorium tersebut dalam kerangka penyempurnaan tata kelola hutan di Indonesia.

Moratorium terhadap izin hak pengusahaan hutan baru di kawasan hutan merupakan langkah penting dalam memenuhi komitmen sukarela Indonesia untuk mengurangi emisi. Namun demikian, beberapa persoalan belum tuntas mengenai luas dan status lahan yang tercakup dalam moratorium, serta jumlah karbon yang tersimpan di hutan dan lahan gambut yang dimaksud. Moratorium semestinya dilihat sebagai alat, bukan tujuan, guna menetapkan keadaan yang memungkinkan untuk mengurangi emisi gas rumah kaca, menyempurnakan tata kelola hutan dan lahan gambut. Ketika mekanisme global seperti REDD+ sedang direncanakan, moratorium dapat membuka jalan bagi keberhasilan pembaruan kebijakan yang jauh melampaui masa berlakunya yang hanya dua tahun.
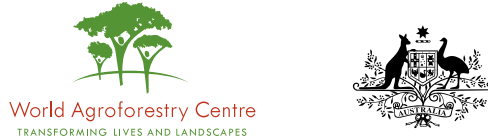

Australian Government

AusAID

Climate and

Land Use Alliance

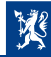

NORWEGIAN MINISTRY OF THE ENVIRONMENT
NORWEGIAN MINISTYY OF FOREIGN AFFAIRS

\section{Center for International Forestry Research}

CIFOR memajukan kesejahteraan manusia, konservasi lingkungan dan kesetaraan melalui penelitian yang berorientasi pada kebijakan dan praktik kehutanan di negara berkembang. CIFOR merupakan salah satu dari 15 pusat penelitian dalam Kelompok Konsultatif bagi Penelitian Pertanian Internasional (Consultative Group on International Agricultural Research - CGIAR). CIFOR berkantor pusat di Bogor, Indonesia dengan kantor wilayah di Asia, Afrika dan Amerika Selatan. 